\title{
The role of the church in the \#FeesMustFall movement in South Africa: Practical Theological reflection
}

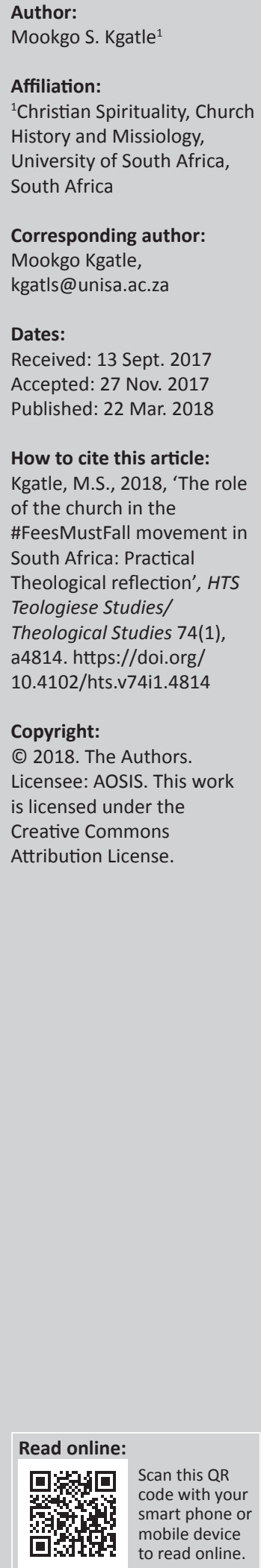

In 2015 and 2016, South Africa experienced one of the unique student-led protests since the dawn of democracy that touched the world, the \#FeesMustFall movement. Out of the many demands that the students made in the movement, one is outstanding, fee-free higher education. A large number of publications have been written on the movement from an economical and educational point of view. Most of these publications argue that a fee-free higher education for all students is not an affordable or sustainable option for South Africa at the moment. What is new in this article is a practical theological reflection on the movement in general and the demand for a fee-free higher education by students in particular. The article looks at the possibilities of fee-free higher education for the poor students in South Africa by exploring the roles of the church in the \#FeesMustFall movement.

\section{Introduction}

\#FeesMustFall is a student-led protest movement that began in mid-October 2015 in response to an increase in fees at South African universities (ENCA 2015). Protests started at the University of Witwatersrand and spread to the University of Cape Town and Rhodes University before rapidly spreading to other universities across the country (EWN 2016). The 2015 protest ended when it was announced by the South African government that there would be no tuition fee increases for 2016. The protest in 2016 began when the South African Minister of Higher Education announced that there would be fee increases capped at $8 \%$ for 2017; however, each institution was given the freedom to decide by how much their tuition would increase (EWN 2017).

During the protest, the students changed their tune from just protesting against fee hike to protest for a fee-free higher education for all. One of the motivations for this protest is the Freedom Charter, which stated in no uncertain terms: 'The doors of learning and culture shall be opened!' It emphasised that:

Education shall be free, compulsory, universal and equal for all children; Higher education and technical training shall be opened to all by means of state allowances and scholarships awarded on the basis of merit. (Freedom Charter 1955)

It is argued here that 'free' and 'compulsory' refer squarely to basic education. Higher education and technical training must 'be opened to all' - that is, made accessible through financial support.

Another motivation is the Constitution of the Republic of South Africa (adopted in 1996) that took forward this promise:

Everyone has the right (a) to a basic education, including adult basic education; and (b) to further education, which the state, through reasonable measures, must make progressively available and accessible. (The Constitution of the Republic of South Africa adopted in 1996)

Students were also motivated by the 2007 African National Congress (ANC) Policy Conference, supporting the previous policy decision, resolved that 'free higher education for the poor up to undergraduate level' must be progressively implemented (National ANC Policy Conference 2007). This was reiterated at the Mangaung Policy Conference (National ANC Policy Conference 2012).

This article reflects on the \#FeesMustFall movement in general and the demand of a free higher education by students in particular. This will be achieved by studying the background, demands and elements of violence in the movement. The article also attempts to make a distinction between fee-free higher education for all and for poor students. ${ }^{1}$ The purpose of this article is to demonstrate 
the roles that the church can play in order for fee-free higher education for the poor students to become a reality.

\section{\#FeesMustFall movement Background}

The immediate trigger appeared to be the announcement by the University of Witwatersrand of a $10.5 \%$ fee increase for 2016, which evoked the response \#FeesMustFall (Badat 2016:12). Other universities joined the University of Witwatersrand, whereby most universities in the country were shut down, as students were demanding a zero increase in fees under the \#FeesMustFall movement (Dunga \& Mncayi 2016:162). The students were also protesting against the poor treatment of workers in support services in universities. The call throughout South Africa was \#FeesMustFall (Economic and Political Weekly 2016). Furthermore, South Africa's bornfrees - the first-generation born after the end of apartheid began to call for the decolonisation of South African universities at the beginning of 2015 (Naicker 2016:54).

This rallying call coalesced into countrywide protests, which enjoyed widespread media coverage and public outcry. What began as a protest over proposed increases soon led to a nationwide call, with thousands of students, workers and parents on the streets in scenes reminiscent of the mass-based people's power movements of the 1970s and 1980s. The protests eventually led to the $0 \%$ increase in fees for 2016 across the university sector (CHE 2016). However, student protests gained momentum again when the South African Minister of the department of higher education Blade Nzimande announced in 2016 that there will be a fee increase capped at 8\% for the academic year 2017 (EWN 2017).

The \#FeesMustFall movement is the culmination of 23 years of broken promises. It is symptomatic of a government that promises its people things that are impossible to deliver for the sake of winning elections. Free higher education was a major campaign commitment made by the ANC in the first democratic elections. Moreover, the debate on free higher education dominated the ANC's last elective conference in Mangaung in 2012. The ruling party's failure to keep such promises, while presiding over an explosion of student fees, have sown the seeds of discontent that have spilled over to the street, the lawns of the Union Buildings and grounds of parliament (UDESMO 2016).

The \#FeesMustFall movement is the tip of the iceberg. It is an example of many other protests going on in South Africa at a local and national level. The \#FeesMustFall movement is a sign of a dissatisfied citizenry in South Africa. This is illustrated by the fact that it was not only the students that took to streets but other population of the society joined to empty their frustrations at the South African government. South Africa is more likely to experience more of these similar protests leading to the national elections in 2019. The service delivery protests are caused by the perception in society that government responds quickly where there are protests.

\section{Violent nature}

The issue of the use of violence in student-led protests featured prominently in the \#FeesMustFall movement. As a result, there were many South Africans who, while supportive of the movement, felt the students should have protested peacefully. As the actions and protests intensified on campuses, the student movement began to be criticised with regard to incidents of vandalism at some campuses (Economic and Political Weekly 2016). The \#FeesMustFall movement was violent, with the torching of some university buildings and chaos throughout the country. Although the President of the country announced a freeze of university fees for the academic year, 2016, violence in some campuses continued unabated (Karodia, Soni \& Soni 2016:76).

\#FeesMustFall, through acts of violence perpetrated in its name, has suffered damage to its credibility. This may be because of others who may have tried to hijack the movement and who may even serve the agendas of others. It would therefore appear to many observers that \#FeesMustFall is no longer about free education for the poor, but it is about causing chaos and instability in institutions of higher education so that they will have to be rebuilt from scratch (SACC 2016).

It is alleged that at some institutions, the student protests were associated with intimidation and violence on the part of some students and/or security companies and/or the police. Some observers generally sympathetic to the student protest movements contend that a few students rationalised the use of violence to achieve demands (Badat 2016:18). Although the violence engulfing the university protests cannot be blamed solely on the police, the dominant feeling among key informants was that the police too easily resorted to shooting protesters with rubber bullets and stun grenades without any attempt at negotiating or engaging with them. Students described their destruction of property as retaliation for the university management deploying police and private security officials in response to their demands (Langa 2016:10).

On Cape Peninsula University of Technology campuses according to Ndelu (2016:26), the private security companies used elevated forms of violence against the students, often exacerbating the damage caused to both the physical structures and the social relations on the campuses. They shot at protesters; used stun grenades to disperse crowds of protesters, including within enclosed residences; physically assaulted protesters; effected citizens' arrests; raided student residences and maintained strict access restrictions. Malabela (2016a:115) adds that the violence at the University of Limpopo started when management called on the security personnel on campus to disperse students who had gathered at Thami Square for a night vigil around \#FeesMustFall. The security personnel then called the police, who, on arrival on campus, arrested the student leaders. The students started being violent as they wanted their leaders to be released. The police responded with violence and started firing rubber bullets at the protesting students. 
Meth (2016) says that protests were peaceful at Rhodes University. They:

involved singing and [lecture] disruptions - not in a violent manner - nothing breaking and no one hurt. Until the day came when police started shooting at students. It was after the first shooting that things became violent. Students started to fight back. Police would just shoot at protesters just singing and that was described as violent - no one ever told the students the rules of engagement. The police misconduct led to the violence. There was a time when students started focusing more on police brutality than actual call - they sparked the violence. Students' only violence was to retaliate against the brutality. (p. 102)

The presence of police and the private security personnel triggered violence in many campuses, including the University of Witwatersrand. Students became angry and reacted with violence and the destruction of property (Malabela 2016b:137). However, Habib, the University of Witwatersrand vice chancellor, countered that the university was forced to act because the protesting students threatened non-protesting students and workers and in some instances attempted arson. They were thus forced to bring in private security and the police. Habib argued that the violence was not caused by the presence of the police and private security; rather, they were brought in response to the violence of the protesting students (Habib 2016).

If indeed private security personnel and police were called in to provoke students to anger, the mistake that the students made was to react and retaliate to such provocation. In conflicts, the person who reacts usually takes the blame even if their concern is genuine. In this context, many citizens blamed the students for turning South African institutions of higher learning into places of violence. On the other hand, the security personnel and the police remained innocent. The violent nature of the protests spoiled the genuine concerns of the students.

Although the students were wrong by reacting to police and security personnel, the government is equally wrong to send such personnel. In urgent matters like \#FeesMustFall, the best way is to engage the people involved rather than sending police and other forces. The \#FeesMustFall protest was an urgent matter and not just an issue of law and order and security force engagement. It should not be treated as a law and order matter only, which is what it seems to be. It is a public policy issue. It needs governmental engagement, and not security force engagement alone (EWN 2016).

In campuses such as Mangosuthu University of Technology, University of Zululand and Walter Sisulu University, intimidation and violence were used to force students into submission. Management demanded that the students be grateful for the chance to be at university in the first place. Meanwhile, many black students have lamented the fact that the kind of brutality they have experienced would never have been inflicted on their white counterparts in South Africa. Precisely because black students are reported as criminal and violent, their claims and concerns are easily dismissed and obscured (Kujeke 2016:85).

Naicker (2016:58) argues against the point that it is only black students who were victimised. Naicker continues to say that the protesting students even at historically white universities now also face the militarisation, violence and repression, although to lesser and varying degrees than subaltern classes face when they organise themselves. The militarisation of campuses and the use of tear gas, stun grenades and water cannons against students at protests prove the ANC's inability to deal with people organising outside the party and they easily resort to violence whenever people step out of their allotted spaces.

The violent nature of the \#FeesMustFall movement is a sign of the society living in violence. Most of the black students go to sleep hungry every day. These students use overcrowded trains to reach the campus. They risk their lives by hanging on the doors of the train. These students hang on trains going to a violent place, the townships. Students are robbed on their way to campus. Female students are sexually harassed by their male fellow students and lecturers (Maringira \& Gukurume 2016:41).

It is not wrong to protest or demonstrate against the authorities or people in higher office. It is not wrong for the students to engage in protest for free education for the poor and/or all. Students are welcome to picket, demonstrate and display their dissatisfaction to the South African government as it is their constitutional right. Students have a right like all citizens to demonstrate their concerns to the authorities. However, criminal elements in such protests should be condemned and unlawful acts of violence in such protests should be exposed by authorities. Perpetrators of crime should be arrested regardless of their socio-economic status (Kgatle 2017:5).

The intimidation of students and staff by activists and protesters should be condoned. The use of violence by any party in this struggle should be rejected. The acts of arson, attacks on people and mob justice should also be condemned. Those responsible must be brought to account and face the consequences of their illegal actions. The unnecessary arrests of and victimisation of students by the authorities that suppress their voices should equally be condemned. Any protest should stay focused on reaching its objective through protesting positively, not negatively, and to engage the negotiating table with reasonable demands (SACC 2016).

\section{The demands of students}

Although spoiled by the violent nature of the protests, the \#FeesMustFall campaign is fully justified because it is the creation, borne out of a just and legitimate demand for free higher education in South Africa (Karodia et al. 2016:82). Students, especially black students, demand Free Higher 
Education, suggesting, inter alia, that the existing funding mechanisms like National Student Financial Aid Scheme ${ }^{2}$ do not sufficiently address financial barriers to higher educational opportunities (Wangenge-Ouma 2012:2). By late 2015/early 2016, the issues raised at University of Cape Town (UCT), Rhodes and Stellenbosch were overtaken by the demands of students at the University of the Witwatersrand and elsewhere related to proposed tuition fee increases, student debt and financial aid, but the main demand was for fee-free higher education (Badat 2016:12).

While the early 2015 protests were aimed at the removal of apartheid symbols such as statues that emphasised the role of colonial and apartheid heroes at universities, the main issue was the \#FeesMustFall demand, fee-free higher education. Students demanded that there should be no increase in tuition fees for the year 2016. In 2016, the revolution intensified the demand for either no fee increase or free university education for all (Musitha 2016:101). The student demands were initially for smaller fee increases, then no fee increases and then for fee-free higher education - in some versions, for the poor, and in other versions, implicitly for all (CHE 2016). The \#FeesMustFall campaign is aimed not only at convincing the government and tertiary institutions to eliminate tuition fees but also at advocating for free tertiary education (KPMG 2016:6).

The questions raised by students and other participants in the struggles around education are not simply about education, nor are they resolvable through better education policies, plans and strategies, or by increasing state budgets for the higher education system, alone. They raised fundamental questions about the very nature of the 'decolonisation' and 'transformation' of post-apartheid society and how 'national development' and its political, socio-economic and cultural goals are to be realised (South Africa History 2016). The protests were a dramatic reminder of unfinished business in higher education, and forcefully placed on the agenda key issues: the 'decolonisation of the university', the social composition of academic staff, institutional culture, the inadequacy of state funding of higher education, the level and escalation of tuition fees, student debt and the question of fee-free higher education (Badat 2016:19).

The students also protested against the outsourcing of university support staff. Rather than outsourcing and privatising university staff, these workers must be employed by the university, thereby allowing them to access the full benefits of being permanent employees. It is also important to recognise that the issue of outsourcing university support staff is not a new one, but it has been neglected for a long time. The students supported the workers on their demand

2.The first recommendation from the National Commission on Higher Education in 1995 was that government should establish a National Student Financial Aid System (NSFAS), and government responded immediately. During its first phase, NSFA became a much admired student grant and loan scheme, delegations from number of countries came to study this scheme. There were, and are, very few successful student financial aid schemes in the third world. However, as the scheme grew, by 2008 there were administrative problems, in the head office and particularly at some universities (Cloete 2015:4) for a minimum wage of R12 500 per month. The students supported this demand because most of their parents work in South African universities as support staff (Economic and Political Weekly 2016).

The students in the \#FeesMustFall movement have made different demands that include decolonisation and transformation of South African universities. Students made other demands like the outsourcing of support staff in South African universities. Out of the many demands that the students made, one is outstanding: fee-free higher education for the poor and/or for all. One cannot just dismiss this demand and call it an insane demand. The question is the possibilities of the free education for the poor and/or for all. How can the demand for fee-free higher education for the poor and/or for all be made possible in South Africa?

\section{Fee-free higher education for all}

It is important according to Cloete (2015:2) to differentiate between fee-free higher education for the poor and free higher education for all - and these are two vastly different concepts, with even bigger implications. Cloete (2016:8) opines that fee-free higher education for all is not a good policy idea. It can actually harm, rather than assist, the poor. A statement by the North-West University (2016) agrees with Cloete that free education for all has proven to reproduce and reinforce inequalities and is not affordable by poor political economies in the long run as increased enrolments require growing resources to sustain quality education.

Instead of free education for all, Cloete (2016:9) suggests that costs must be shared between different stakeholders. The student choice must be unconstrained by socio-economic status; the risk of inability to pay must be pooled; costsharing must be separated from marketing; and there needs to be progressive redistribution. Furthermore, the retirement age of graduates must be increased (graduates have a higher life expectancy than non-graduates) and for the public savings from longer contribution to the system and later withdrawal of benefits to be used to increase public funding for universities. This is just one example of a proposal for shifting fees from students to graduates. In other words, there could be fee-free higher education for students, if graduates repay over a long period.

There is an agreement by the organisation under the name Universities South Africa that the principle of a cost-sharing model as proposed by Cloete to cater for the cost of the public goods of higher education on the one hand and that of the private goods on the other. The main funding sources of higher education, therefore, are the fiscus-based state subsidy system and private contribution (in the form of tuition fees and/or other sources of funding). As such a fee-free higher education system is not supported unless there is clarity on how the full higher education budget will be constructed to maintain current levels and quality of service delivery (Universities South Africa 2016). 
Fee-free higher education for all students is not an affordable or a sustainable option for South Africa. The knowledge and skills acquired in the course of achieving higher education qualifications generate significant lifetime private benefits for successful students as well as long-range social benefits for the public at large. Although higher education institutions admit an increasingly large proportion of students from poor families, students from middle-class and wealthy families still tend to be disproportionately well-represented. For all these reasons, the costs of higher education should be shared equitably between public and private beneficiaries (Department of Higher Education and Training 2012:59).

Free higher education for all is not possible because, according Dunga and Mncayi (2016:170), the country has no capacity to offer fee-free higher education for all and that forcing it would lead to a compromised quality. Fee-free higher education would strain the resources, which are not enough in any case. Furthermore, it might end up benefiting the rich who do not need help with paying for their education. Fee-free higher education policy should only be allowed if it is only targeting needy and academically deserving students.

\section{Fee-free higher education for the poor}

In support of fee-free higher education for the poor, Badat (2016:22) argues that there should be no blanket objection to the ideal of fee-free higher education. Badat continues to say that fee-free higher education for the poor can be possible in South Africa and is a question of making reasoned public choices and of understanding the consequences of public policies of fee-free higher education for the poor. A policy of fee-free higher education requires fundamental re-thinking of and changes in social goals, priorities and policies by the government. In addition, the government would have to provide universities their full running costs, part of which they currently derive from tuition and residence fees from students. This would total tens of billions. Absent this, without fees universities would collapse (Badat 2016:22).

One of the ways to achieve fee-free higher education for the poor would be to redirect funds from some of the dysfunctional Sector Training Authorities (Odhav 2009:44). The government could also redirect some of the current education expenditure to the cause of fee-free higher education for the poor through, for example, reducing the costs of the construction of education infrastructure through a more effective National Youth Service, which will require every young person at a particular level of education to participate in a mass school building programme (Lubisi 2008:15).

Another way to realise fee-free higher education for the poor is for the government to increase funding by at least an aggregate amount equal to the ratio achieved in Organisation for Economic Cooperation and Development (OECD) countries. In 2011, South Africa's state budget for universities as a percentage of gross domestic product was $0.75 \%$, which is more or less in line with Africa as a whole $(0.78 \%)$. But it lags behind when compared with OECD countries (1.21\%) and the rest of the world (0.84\%) (the conversation 2016).

The government must deal with corruption and irregular expenditure if it is serious about prioritising education and supporting the poor in this regard. Udesmo (2016) says that:

Irregular expenditure and corruption is between 25-30 billion Rands per annum, which along with other measures proposed, could easily fund fee-free higher education. For instance, in 2011 alone, the country lost R237 billion in illicit financial flows (IFFs) and in eight years, 2002 to 2010, over R 1 trillion. This besides preventive measures including the Financial Intelligence Centre Act (FICA), the Financial Advisors and Intermediate Services Act (FAISA) and the Financial Regulation Bill-FRB. If government tackles Illicit Financial Flows (IFFs) for 2017/8 alone, there shall be sufficient funds to provide free quality tertiary education for the poor. This could be achieved without changing any law, but simply enforcing existing ones. It would further assure an abundant surplus for further planning, upgrading and qualitative transformation of tertiary education.

The introduction of fee-free higher education for poor and working-class students is particularly feasible because, on the one hand, the poor constitute an overwhelming majority of students at relatively cheap Historically Disadvantaged Institutions such (e.g. University of Venda) and Universities of Technology (e.g. Tshwane University of Technology), and on the other hand, they constitute a minority of students at expensive elite universities such as University of Witwatersrand, Stellenbosch University and the University of Cape Town (Thusanani Foundation 2016:16).

Moreover, there is a need to think about the role of education in society and give content to a set of 'transitional' demands, which can widen access to higher education, especially for working-class and rural communities. To that extent, they could be useful for prizing open the possibilities for achieving the broader social goals and push back the dominant neoliberal approaches to policy and practice (Motala, Vally \& Maharajh 2016:14). The demand for Fee-Free Higher Education for the poor in South Africa is considered a legitimate request that deserves interrogation. Indeed, numerous jurisdictions are scrapping university tuition fees as a means of providing access to higher education, namely, Sweden, Norway, Germany and the Province of Ontario (for those from families earning below a particular threshold). For the most part, this scrapping of tuition fees is being financed by increased taxation collected by provincial or municipal governments (University of Witwatersrand 2016).

The case for fee-Free Higher Education for the poor is based on two main premises: (1) social justice: increasing access for the poor, especially previously marginalised communities, to university education in the face of increasing tuition fees; and (2) growth externalities. Given South Africa's high levels of skills shortages, fee-Free Higher Education for the poor is deemed necessary to get human capital investment to efficient levels (Wangenge-ouma 2012:9). The most rational 
way to deal with fee-free higher education is to have fees which are uncontrolled, with no cap, but in return universities have to make adequate provision for looking after students who cannot afford to pay that fee (Submission to the Presidential Commission 2016:3).

The first is that in order to maintain the best postgraduate system in Africa and to allow for successful access, universities must be differentiated into institutional types, somewhat like the most successful higher education system in the world. There should be a range of institutions - from community colleges (remedial schools with some vocational offerings) and undergraduate universities to some worldclass research universities (Cloete 2016:8).

The government of South Africa as led by the ANC will therefore be able to implement fee-free higher education for the poor and live up to its revolutionary credentials and all living in South Africa will be afforded education and access must be open to all (Karodia et al. 2016:80).

\section{The roles of the church Sociocultural role}

The first role is called a sociocultural calling. The church has a definite formative sociocultural calling in the world in line with its prophetic, priestly and kingly tasks; it thus needs to make its influence felt in the world in relation to other societal institutions and the community in general through its own and its individual members' Christian testimonies in the world. Christianity in South Africa must, therefore, assume a sociocultural form so that it may be a formative power in South African society and in South African societal institutions, such as schools, the state, industrial communities, et cetera (Jansen, Pretorius \& Van Niekerk 2009:80).

The church should work hand in hand with civil society to expand access in the public sector. Initiatives have been introduced in a bid to increase the proportion of black students at universities. These came about as a result of pressure from civil society and aimed at alleviating years of exclusion that black students have experienced. The initiatives, while controversial, seem to have been successful in making access to free higher education more equitable (Student Leaders 2016:57). It is suggested here that helping poor students on the part of civil society cannot operate in a sociopolitical and economic void. Taking this position into account means that the initiatives of civil society are interlinked to those of government. It is a matter of the existing policy environment and the manner in which the government operationalises such policies to dovetail its efforts and those of civil society in helping poor students (Noyoo 2009:24).

The church in its sociocultural role should support universities to drive knowledge, which is a key to social and economic development in our globalising world. Universities should be supported to inculcate the high-level skills that are currently so scarce and so urgently needed across the public and private sectors; they should be supported to produce new and apply existing knowledge to areas of social and economic need and, in so doing, contribute to the cultural and moral development of the nation; and also be on the forefront of innovation, which provides opportunities to ordinary citizens and thus promotes social mobility and enhances social justice (NPC 2011:262).

Furthermore, supporting universities will make sure that they remain crucial to development in democratic societies where they are mandated to advance the system of knowledge that can be useful for the multiplicity of related roles for achieving the values and goals of a democratic society. Especially in societies that are in transition from a traumatic past - as in the case of South Africa - this role has to be discharged through a dedicated response. This mandate requires universities to respond to the many and pronounced challenges faced by the state and society in its transformation, including those emanating from a raft of social, economic, political, environmental and other challenges among which are the intractable issues of inequality, poverty and unemployment (Fees Commission 2016:5).

\section{Socio-economic role}

The second role is called a socio-economic calling. Deuteronomy 15:7-8 says that if in any of the towns in the land that the Lord your God is giving you there is a fellow Israelite in need, then do not be selfish and refuse to help him. Instead, be generous and lend him as much as he needs. In South Africa there are fellow citizens who need economic or financial help to further their studies. 1 Corinthians 10:24 states that none of you should be looking out for your own interests, but for the interests of others. Romans 12:13 says to share your belongings with your needy fellow Christians, and open your homes to strangers. Proverbs 28:27 states that: He that gives unto the poor shall not lack: but he that hides his eyes shall have many a curse. Proverbs 19:17 states that: He that hath pity upon the poor lends unto the LORD; and that which he hath given will he pay him again.

Helping the poor is about demonstrating love unto other people. 1 John 3:17 says that rich people who see a brother or sister in need, yet close their hearts against them, cannot claim that they love God. James 2:15-16 says that suppose there are brothers or sisters who need clothes and do not have enough to eat. What good is there in your saying to them, 'God bless you? Keep warm and eat well!' - If you don't give them the necessities of life? One of the necessities of life in this context is education.

To minister to the poor is what Jesus Christ has come to do. Do not preach Christ if you are not ready to minister unto the poor and the needy in life. In Luke 4:18-19, Jesus said that the Spirit of the Lord is upon me, because he has chosen me to bring good news to the poor. He has sent me to proclaim liberty to the captives and recovery of sight to the blind; to set 
free the oppressed and announce that the time has come when the Lord will save his people.

The church can work with business and charitable institutions from the public (outside education) and private sector. Although these sources of funding are precarious and unsustainable because they carry no legal obligation to fund students in the first place-not even in the case of parents, the majority of whom are most likely to be dependent on bank loans for such funding - they can still play a meaningful role to provide fee-free education (Submission to the Inquiry in Higher Education 2016:4).

The church should encourage businesses to use the wealth of their companies to fund tertiary education of South Africa, but they should not be celebrated for stealing resources while destabilising the livelihoods of employees. Some businesses give stolen money to an exclusionary institution so that the graduates thereof can enter a capitalist system and further entrench the exploitative legacy of their benefactors. In the perspective of big business, donating money to elite universities is more worthwhile than compensating their employees (Student Leaders 2016:9).

There is no doubt that the private sector has a role to play. They already provide numerous bursaries to South African students that run into millions of Rands. Indeed the private sector, and particularly big business in South Africa, has to be engaged in an orderly manner, without double-speak and threats by higher authorities. Business has a fundamental and pivotal role to play with regards to higher education, contributing to the skills deficit that has plagued the country, growing the economy and contributing to the stability of the nation by addressing the very high unemployment rates and addressing the poverty and inequality that permeates South African society (Karodia et al. 2016:77).

\section{Sociopolitical role}

The third role is a sociopolitical calling. The church should be a prophetic voice to the government of the day and speak to their wrongdoings. The government is capable of helping the poor but hindered by corruption and maladministration. The church should rise and confront such challenges the same way it did against apartheid and other evil systems.

The church should provide the moral fibres needed in society. The church can influence the response to poverty by having an ethical impact when principles benefiting all in society are applied within economic systems. They can also influence the response to fee-free higher education by fostering an attitude of willingness to practise generosity. The church can educate communities in order for human dignity of all in society to be restored. The church can be part of the system by actively encouraging and participating in the fee-free education (Beyers 2014:1).

The church can contribute to the establishment of an ethos of human dignity, human rights, reconciliation and peace that can be introduced by civil society into the generalised discourse regarding moral regeneration (Vorster 2015:5). The establishment of an ethos of human dignity can be done by mediating Christ to society. The church should concentrate on the transforming power of the kingdom of God in acting out its role in society. It is a call for a kind of intervention that will lead to a change of attitude in society (De Wet \& Kruger 2013:2).

\section{Conclusion}

In the years 2015 and 2016, South Africa experienced one of the unique student-led protests since the dawn of democracy that touched the world, the \#FeesMustFall movement. Most of the publications on \#FeesMustFall argue that a fee-free higher education for all students is not an affordable or sustainable option for South Africa at the moment. While some argue that fee-free higher education for the poor is possible, the question is how that can be possible? In order to answer the how question, this article proposed different roles that the church can play to make free higher education for the poor to become a reality. The roles include sociocultural, socio-economic and sociopolitical roles.

\section{Acknowledgements Competing interests}

The author declares that he has no financial or personal relationships which may have inappropriately influenced him in writing this article.

\section{References}

Badat, S., 2016, Deciphering the meanings, and explaining the South African Higher Education student protests of 2015-16, Pax Academica, Johannesburg, pp. 71-98.

Beyers, J., 2014, 'The effect of religion on poverty', HTS Teologiese Studies/Theological Studies 70(1), Art. \#2614, 1-8. https://doi.org/10.4102/hts.v70i1.2614

Cloete, N., 2015, The ideology of free higher education in South Africa: The poor and middle class subsidising the rich, Centre for Higher Education Trust, viewed 05 October 2015, from www.chet.org.za

Cloete, N., 2016, Free higher education: Another self-destructive South African policy, Paper published by the Centre for Higher Education Trust (CHET), viewed 20 January 2016, from www.chet.org.za

CHE, 2016, Advice to the Minister of Higher Education and Training on Fee Adjustments at Public Universities for 2017, viewed 11 August 2016, from www.che.ac.za

Department of Higher Education, 2012, annual report of department of higher education, viewed 31 May 2013, from www.dhet.gov.za

Department of Higher Education, 2016, Report of the working group on fee free University education for the poor in South Africa, viewed 10 October 2016, from www.dhet.gov.za

De Wet, F.W. \& Kruger, F.P., 2013, 'Blessed are those that hunger and thirst for righteousness: Sharpening the ethical dimension of prophetic preaching in a context of corruption', Verbum et Ecclesia 34(1), Art. \#722, 1-10. https://doi. org/10.4102/ve.v34i1.722

Dunga, S.H. \& Mncayi, P., 2016, 'Determinants of the perceptions of free higher education among students at a South African university', International Journal of Economics and Finance Studies 8(1), 161-176.

Economic and Political Weekly, 2016, Apartheid has not ended: \#FeesMustFall Movement in South Africa, viewed 09 December 2016, from www.epw.in

ENCA, 2015, Protests grow over university fee hikes, viewed 23 October 2015, from www.enca.com

EWN, 2016, Zuma should address nation over tertiary fees matter-SACC, viewed 10 October 2016, from www.ewn.co.za

Freedom Charter adopted at the congress of the people at Kliptown, Johannesburg, 1955, viewed 25 June 2015, from www. historicalpapers.wits.ac.za

Habib, A., 2016, 'Op-ed: The politics of spectacle - Reflections on the 2016 student protests', Daily Maverick, viewed 05 December 2016, from www.dailymaverick. co.za 
Jansen, C.A., Pretorius, F.J. \& Van Niekerk, E.J., 2009, 'Education and the role of the church in Africa: Three relevant aspects', Koers 74(1-2), 67-85. https://doi. org/10.4102/koers.v74i1/2.117

Karodia, A.M., Soni, D. \& Soni, P., 2016, 'Research journal of education', Research Journal of Education 2(5), 76-89.

Kgatle, M.S., 2017, 'The causes and nature of the June 2016 protests in the city of Tshwane: A practical theological reflection', HTS Teologiese Studies/Theological Studies 73(3), a3845. https://doi.org/10.4102/hts.v73i3.3845

KPMG, 2016, The economics of \#FeesMustFall: Economic challenges to accessing tertiary education and providing tuition-free universities in South Africa, viewed 05 October 2016, from www.sablog.kpmg.co.za

Kujeke, M., 2016, 'Violence and the \#FeesMustFall Movement at the University of KwaZulu-Natal', in M. Langa (ed.), An analysis of the \#FeesMustFall Movement at South African University, pp. 83-96, Centre for the Study of Violence and Reconciliation, Johannesburg.

Langa, M., 2016, An analysis of the \#FeesMustFall Movement at South African University, Centre for the Study of Violence and Reconciliation, Johannesburg.

Lubisi, C.R., 2008, The quest for free education in South Africa: How close is the dream to the reality? Centre for Education Policy Development, Solomon Mahlangu Education Lecture on 17 June 2008, viewed 17 June 2008, from www. cepd.org.za

Malabela, M., 2016a, 'We are already enjoying free education: Protests at the University of Limpopo (Turfloop)', in M. Langa (ed.), An analysis of the \#Fees MustFall Movement at South African University, pp. 108-120, Centre for the Study of Violence and Reconciliation, Johannesburg.

Malabela, M., 2016b, 'We are not violent but just demanding free decolonized education: University of the Witwatersrand', in M. Langa (ed.), An analysis of the \#FeesMustFall Movement at South African University, pp. 132-152, Centre for the Study of Violence and Reconciliation, Johannesburg.

Maringira, G. \& Gukurume, S., 2016, 'Being Black' in \#FeesMustFall and \#FreeDecolonisedEducation: Student Protests at the University of the Western Cape', in M. Langa (ed.), An analysis of the \#FeesMustFall Movement at South African University, pp. 33-48, Centre for the Study of Violence and Reconciliation, Johannesburg.

Meth, O., 2016, '\#FeesMustFall at Rhodes University: Exploring the dynamics of student protests and manifestations of violence', in M. Langa (ed.), An analysis of the \#FeesMustFall Movement at South African University, pp. 97-107, Centre for the Study of Violence and Reconciliation, Johannesburg.

Motala, E., Vally, S. \& Maharajh, R., 2016, Education, the state, and class inequality: The case for Free Higher Education in South Africa, viewed 20 October 2016, from www.research.gate.net

Musitha, M.E., 2016, 'State and revolution: Reflections from South African institutions of higher learning', Journal of Public Administration and Governance 6(4), 98-109. https://doi.org/10.5296/jpag.v6i4.10312

Naicker, C., 2016, 'From Marikana to \#feesmustfall: The praxis of popular politics in South Africa', Urbanisation 1(1), 53-61. https://doi.org/10.1177/ 2455747116640434

National Policy Conference of African National Congress 2007, Gallagher Estate, Midrand from 27 to 30 June 2007, viewed 30 June 2007, from www.anc.org.za
National Policy Conference of African National Congress 2012, Gallagher Estate, Midrand from 26 to 29 June 2012, viewed 26 June 2012, from www.anc.org.za

Ndelu, S., 2016, “'A Rebellion of the Poor":1 Fallism at the Cape Peninsula University of Technology', in M. Langa (ed.), An analysis of the \#FeesMustFall Movement at South African University, pp. 13-32, Centre for the Study of Violence and Reconciliation, Johannesburg.

NPC, 2011, National development plan: Vision for 2030, National Planning Commission, Pretoria.

North West University, 2016, \#FeesMustFall and beyond: Towards a sustainable National Student Loan regulatory framework - North West University view, North West University, Potchefstroom.

Odhav, K., 2009, 'South African post-apartheid Higher Education policy and its marginalisations: 1994-2002', SA-eDUC Journal 6(1), 33-57.

SACC, 2016, Fees must fall protests and the state of our nation statement from pulpits by his people and every nation churches in South Africa, viewed 16 October 2016, from www.facebook.com

South Africa History, 2016, Education, the state, and class inequality: The case for free higher education in South Africa, viewed 27 September 2016, from www. sahistory.org.za

Student Leaders, 2016, Why neoclassical arguments against free education are Bullshit and why we need free education, viewed 20 August 2016, from www. docplayer.net

Submission to the commission of inquiry into higher education and training (fees commission), viewed 26 May 2016, from www.justice.gov.za

Submission to the Presidential Judicial Commission, 2016, Free education for our total liberation, viewed 30 June 2016, from www.justice.gov.za

The Constitution of the Republic of South Africa, 1996, Adopted on 08 May 1996 and amended on 11 October 1996 by the Constitutional Assembly, viewed 11 October 1996, from www.justice.gov.za

The Conversation, 2016, How to take free public higher education from pipedream to reality, viewed 11 June 2016, from www.theconversation.co.za

Thusanani Foundation, 2016, Thusanani Foundation's Presentation to the "Fees Commission": A case for redistributive justice and collective social mobility in South African Higher Education, viewed 10 August 2016, from www.justice.gov.za

UDESMO, 2016, Fees must fall \#FeesMustFall movement, viewed 29 October 2016, from www.justice.gov.za

Universities South Africa, 2016, Universities Funding in South Africa; a Fact Sheet, viewed 26 October 2016, from www.uct.ac.za

University of Witwatersrand, 2016, Report of the university panel of funding models for higher education in South Africa, viewed 30 June 2016, from www.wits.ac.za

Vorster, J.M., 2015, 'The possible contribution of civil society in the moral edification of South African society: The example of the "United Democratic Front" and the "Treatment Action Campaign" (1983-2014)', HTS Teologiese Studies/Theological Studies 71(3), Art. \#2754, 1-8. https://doi.org/10.4102/hts.v71i3.2754

Wangenge-Ouma, G., 2012, 'Tuition fees and the challenge of making higher education a population commodity in South Africa. Higher education', OnlineFirst, 28 April, pp. 1-16. https://doi.org/10.1007/s10734-012-9531-6 